\title{
Effect of regular terbutaline on the airway response to inhaled budesonide
}

\author{
Paul J Wilding, Miranda M Clark, Janet Oborne, Jon A Bennett, Anne E Tattersfield
}

\begin{abstract}
Background - The rebound increase in bronchial reactivity and fall in forced expiratory volume in one second $\left(F E V_{1}\right)$ following treatment with $\beta$ agonists seen in several studies has occurred regardless of concurrent steroid therapy. Little is known about the effect of adding $\beta$ agonists to corticosteroids, but in a recent study regular treatment with terbutaline appeared to reduce some of the beneficial effects of budesonide. The effects of budesonide alone and in combination with regular terbutaline treatment on lung function, symptom scores, and bronchial reactivity were therefore examined.
\end{abstract}

Methods - Sixteen subjects with mild stable asthma inhaled budesonide $800 \mu \mathrm{g}$ twice daily for two periods of 14 days with terbutaline $1000 \mu \mathrm{g}$ three times daily or placebo in a double blind crossover fashion. $F E V_{1}$ and the dose of histamine or adenosine monophosphate (AMP) causing a $20 \%$ fall in FEV $_{1}\left(\mathbf{P D}_{20}\right)$ were measured before and 12 hours after the final dose of treatment, and changes from baseline were compared. Seven day mean values for daily morning and evening peak expiratory flow (PEF) values, symptom scores, and rescue medication were compared before and during treatment.

Results - Morning and evening PEF rose more with budesonide plus terbutaline than with budesonide alone, with a mean difference of $19 \mathrm{1} / \mathrm{min}$ occurring in the evening (95\% confidence interval (CI) 2 to 36). There was no difference in symptom scores during treatment. Following treatment the mean increase in $\mathrm{FEV}_{1}$ was $150 \mathrm{ml}$ higher with budesonide alone $(95 \% \mathrm{CI}-10$ to 300). There was no difference between treatments in change in histamine and AMP $\mathbf{P D}_{20}$.

Conclusions - Evening PEF was greater when budesonide was combined with regular terbutaline. There was no evidence of a difference in bronchial reactivity following the two treatment regimens. The findings of a previous study were not confirmed as the reduction in $F E V_{1}$ after budesonide and terbutaline was smaller and not statistically significant. Further work is needed to determine whether this disparity in findings in the two studies is due to a type 2 statistical error in this study or a spurious finding in the previous study. (Thorax 1996;51:989-992)

Keywords: $\beta$ agonists, corticosteroids, lung function.
High doses of $\beta$ agonists have been associated with epidemics of asthma deaths $s^{1-5}$ and, in some studies, regular exposure to $\beta$ agonists has had deleterious effects on lung function ${ }^{6-11}$ and bronchial reactivity ${ }^{911-15}$ once the acute bronchodilator effect has worn off. The mechanism of these effects is unclear but they appear to occur regardless of whether subjects are taking corticosteroids or not ${ }^{9}$ and may even be greater in patients taking corticosteroids. ${ }^{1617}$ Although inhaled $\beta$ agonists and corticosteroids are the mainstay of asthma treatment, relatively little is known about the interaction between these agents. Some early studies looked at the effect of adding a glucocorticoid to a $\beta$ agonist and found an additive rather than synergistic interaction in acute dose response studies. ${ }^{1819}$ The effect of adding regular $\beta$ agonist therapy to inhaled steroids has not been studied in detail. In a recent study in which we examined the airway effects of budesonide alone and in combination with terbutaline, terbutaline appeared to reduce the beneficial effects of budesonide on lung function and its protection against the early response to allergen. ${ }^{20} \mathrm{~A}$ negative interaction between $\beta$ agonists and steroids has also been seen at a molecular level in the human lung in vitro. ${ }^{21} \mathrm{~A}$ negative interaction could possibly explain some of the adverse effects of regular $\beta$ agonist therapy. In this study we have examined the effects on lung function and bronchial reactivity of two weeks treatment with inhaled budesonide given alone and in combination with terbutaline in 16 subjects with mild stable asthma. Subjects were also challenged with inhaled histamine and adenosine monophosphate (AMP), stimuli which cause bronchoconstriction via direct and indirect mechanisms, respectively.

\section{Methods}

SUBJECTS

Sixteen non-smoking subjects (three women) aged 25-55 years were recruited. Subjects had a forced expiratory volume in one second $\left(\mathrm{FEV}_{1}\right)$ of $70 \%$ predicted or more, an increase in $\mathrm{FEV}_{1}$ of at least $15 \%$ after inhaled terbutaline $500 \mu \mathrm{g}, \mathrm{PD}_{20} \mathrm{FEV}_{1}$ (dose of histamine causing a $20 \%$ fall in $\mathrm{FEV}_{1}$ ) of $4 \mu \mathrm{mol}$ histamine or less, and a positive skin test to at least two commonly tested allergens. Subjects were receiving no treatment other than an inhaled $\beta$ agonist at least three times per week, and had stable asthma with no exacerbation of their symptoms or respiratory tract infection in the six weeks prior to the study. Subjects gave written informed consent to the study which 


\begin{tabular}{|c|c|c|c|c|}
\hline & Baseline & During treatment & Change from baseline $(95 \% \mathrm{CI})$ & $\begin{array}{l}\text { Mean within subject difference between } \\
\text { treatments ( } 95 \% \mathrm{CI} \text { ) (combination } \\
\text { versus budesonide alone) }\end{array}$ \\
\hline \multicolumn{5}{|l|}{ PEF (am) } \\
\hline $\begin{array}{l}\text { Budesonide }+ \text { placebo } \\
\text { Budesonide }+ \text { terbutaline }\end{array}$ & $\begin{array}{l}470(80) \\
483(72)\end{array}$ & $\begin{array}{l}503(80) \\
525(77)\end{array}$ & $\begin{array}{l}33(12 \text { to } 55) \mathrm{p}<0.01 \\
42(15 \text { to } 70) \mathrm{p}<0.01\end{array}$ & $9(-11$ to 28$) \mathrm{p}>0.3$ \\
\hline $\begin{array}{l}\text { PEF }(\mathrm{pm}) \\
\text { Budesonide }+ \text { placebo } \\
\text { Budesonide + terbutaline }\end{array}$ & $\begin{array}{l}489(71) \\
495(60)\end{array}$ & $\begin{array}{l}503(71) \\
529(69)\end{array}$ & $\begin{array}{l}14(-0.8 \text { to } 29) \mathrm{p}>0.06 \\
33(20 \text { to } 46) \mathrm{p}<0.01\end{array}$ & $19(2$ to 36$) \mathrm{p}<0.05$ \\
\hline $\begin{array}{l}\text { Diurnal variability (amplitude } \\
\text { Budesonide + placebo } \\
\text { Budesonide + terbutaline }\end{array}$ & $\begin{array}{l}7.7(5.4) \\
6.8(6.4)\end{array}$ & $\begin{array}{l}4.6(3) \\
5.7(3.3)\end{array}$ & $\begin{array}{l}3.1(0.3 \text { to } 5.9) \mathrm{p}<0.05 \\
1.1(-2.4 \text { to } 4.7) \mathrm{p}>0.5\end{array}$ & $-2.0(-9.4$ to 1$) \mathrm{p}>0.1$ \\
\hline
\end{tabular}

All values are seven day mean values before and during treatment.

was approved by the Nottingham City Hospital ethics committee.

\section{MEASUREMENTS}

$\mathrm{FEV}_{1}$ was measured with a dry bellows spirometer (Vitalograph, Vitalograph Ltd, Bucks, $\mathrm{UK})$ as the higher of two measurements within $100 \mathrm{ml}$ and peak expiratory flow rate (PEF) as the best of three readings using a mini Wright peak flow meter (Airmed UK). Bronchial reactivity was measured with a dosimeter (Mefar dosimeter MB3, Mefar SRL, Bovezzo, Italy) with subjects inhaling from functional residual capacity to total lung capacity (inhalation time one second, pause time six seconds, pressure $152 \mathrm{kPa}$, output $4 \mu \mathrm{l} /$ puff). Subjects inhaled three puffs of saline followed by doubling doses of histamine or AMP in dose ranges of $0.02-42.9 \mu \mathrm{mol}$ for histamine and 0.09-96 $\mu \mathrm{mol}$ for AMP. FEV 1 was measured two minutes after each dose and the test was stopped when $\mathrm{FEV}_{1}$ had fallen by $20 \%$ from the post-saline value. $\mathrm{PD}_{20} \mathrm{FEV}_{1}$ was calculated by linear interpolation of the last two readings on the log dose response plot. Subjects recorded PEF twice daily before treatment on a diary card throughout the study plus rescue bronchodilator use and symptom scores for night time and daytime symptoms (each on a 5 point scale; $0=$ no symptoms, 4 (at night) $=$ awoke twice or more due to chest tightness and (for daytime) $=$ symptoms so severe that the subject could not go to work or perform usual activities).

\section{PROTOCOL}

This was a double blind randomised crossover study in which subjects inhaled budesonide dry powder (Turbohaler) $800 \mu \mathrm{g}$ twice daily for two 14 day periods in open fashion together with either placebo or terbutaline $1000 \mu \mathrm{g}$ three times daily (Turbohaler) in a double blind fashion. Subjects used ipratropium bromide (Atrovent, Boehringer Ingelheim) for symptom relief throughout the study. After a two week run-in period subjects attended in the morning for measurement of $\mathrm{FEV}_{1}$ and $\mathrm{PD}_{20}$ histamine, followed one hour later by $\mathrm{PD}_{20} \mathrm{AMP}$. Subjects then inhaled the study medication for 14 days, taking the last doses of budesonide and placebo/ terbutaline on the evening of day 14. They returned 12 hours later on the morning of day 15 for repeat measurements of $\mathrm{FEV}_{1}, \mathrm{PD}_{20}$ histamine, and $\mathrm{PD}_{20}$ AMP. Subjects then entered a four week washout period in which they used their usual $\beta$ agonist for symptom relief for the first two weeks and ipratropium for the second two weeks, before crossing over to the second treatment period. Timing of measurements was kept constant for each subject and treatment order was randomised. The study design gave $95 \%$ power to detect a difference between treatments of $160 \mathrm{ml}$ for $\mathrm{FEV}_{1}$ and 1.4 doubling doses for bronchial reactivity at the $5 \%$ significance level.

\section{ANALYSIS OF DATA}

$\mathrm{PD}_{20}$ values were log transformed prior to analysis and are expressed as geometric mean values. Change in $\mathrm{PD}_{20}$ was measured in doubling doses of constrictor agonist. Analysis of variance was used to determine whether there was any period or order effect of treatment and to compare baseline values for $\mathrm{FEV}_{1}$ and $\mathrm{PD}_{20}$ histamine and AMP on day 1 of each treatment period. Changes from baseline values in FEV and $\mathrm{PD}_{20}$ histamine and $\mathrm{AMP}$ after treatment (day 1 versus day 15) were compared between treatments by the paired $t$ test. Symptom scores, use of ipratropium, and PEF were calculated for each subject as the total for the last seven days of the run-in/washout and treatment periods, and changes in symptom scores and use of ipratropium from baseline were compared during treatment by the Wilcoxon ranked sum test. PEF is also represented as amplitude percent mean (am - pm/mean $\times 100 \%){ }^{22}$ Changes in PEF during treatment were compared by the $t$ test. Mean values are given with $95 \%$ confidence intervals ( $95 \% \mathrm{CI}$ ).

\section{Results}

Three of the 16 subjects were withdrawn, two for non-compliance with visits and one for an upper respiratory tract infection whilst taking budesonide and placebo. Mean $\mathrm{FEV}_{1}$ was $78 \%$ predicted and mean PEF $88 \%$ predicted. There were no treatment order or period effects and no significant differences in mean baseline values for $\mathrm{FEV}_{1}$ or $\mathrm{PD}_{20}$ histamine or $\mathrm{AMP}$.

PEF, SYMPTOM SCORES, AND IPRATROPIUM USE Changes in seven day mean values of PEF during treatment are presented in table 1 . Morning and evening PEF increased from 
Table 2 Mean (SD) FEV and $P D_{20}$ histamine and AMP before and 12 hours after the final dose of budesonide with terbutaline or placebo

\begin{tabular}{|c|c|c|c|c|}
\hline & Baseline & After treatment & Change* $(95 \%$ CI $)$ & $\begin{array}{l}\text { Mean within subject difference between } \\
\text { treatments ( } 95 \% \mathrm{CI} \text { ) (combination } \\
\text { versus budesonide alone) }\end{array}$ \\
\hline $\begin{array}{l}\mathrm{FEV}_{1}(\mathrm{l}) \\
\text { Budesonide + placebo } \\
\text { Budesonide + terbutaline }\end{array}$ & $\begin{array}{l}2.69(0.55) \\
2.7(0.47)\end{array}$ & $\begin{array}{l}2.9(0.62) \\
2.76(0.52)\end{array}$ & $\begin{array}{l}0.21(0.1 \text { to } 0.32) \mathrm{p}<0.01 \\
0.06(-0.1 \text { to } 0.22) \mathrm{p}>0.4\end{array}$ & $-0.15(-0.3$ to 0.01$) \mathrm{p}=0.06$ \\
\hline $\begin{array}{l}\mathrm{PD}_{20} \text { histamine }(\mu \mathrm{mol}) \\
\text { Budesonide }+ \text { placebo } \\
\text { Budesonide }+ \text { terbutaline }\end{array}$ & $\begin{array}{l}0.24 \\
0.17\end{array}$ & $\begin{array}{l}0.39 \\
0.35\end{array}$ & $\begin{array}{l}0.7(-0.07 \text { to } 1.36) p>0.06 \\
1.03(0.5 \text { to } 1.6) p<0.01\end{array}$ & $0.34(-0.5$ to 1.26$) \mathrm{p}>0.3$ \\
\hline $\begin{array}{l}\mathrm{PD}_{20} \mathrm{AMP}(\mu \mathrm{mol}) \\
\text { Budesonide + placebo } \\
\text { Budesonide + terbutaline }\end{array}$ & $\begin{array}{l}6.46 \\
4.57\end{array}$ & $\begin{array}{l}8.9 \\
6.46\end{array}$ & $\begin{array}{l}0.46(-0.83 \text { to } 1.79) \mathrm{p}>0.4 \\
0.5(-0.56 \text { to } 1.59) \mathrm{p}>0.3\end{array}$ & $0.04(-1.53$ to 1.59$) \mathrm{p}>0.9$ \\
\hline
\end{tabular}

$\mathrm{PD}_{20}$ values are geometric mean values; ${ }^{*}$ change in $\mathrm{PD}_{20}$ is in doubling doses.

baseline values with both treatment regimens. The increase in morning PEF was similar for both treatments (42 versus $33 \mathrm{l} / \mathrm{min}$ for budesonide with and without terbutaline), whereas the increase in evening PEF was significantly greater after the combination of budesonide and terbutaline (33 versus $14 \mathrm{l} /$ min; mean difference $19 \mathrm{l} / \mathrm{min}$ (95\% CI 2 to $36) ; \mathrm{p}<0.05)$. The smaller increase in evening PEF with budesonide alone caused a trend towards greater reduction in diurnal variability in this group which was not significant.

There was no difference in the change in daytime and night time symptom scores between treatment with budesonide alone and budesonide plus terbutaline. The distribution of symptom scores was skewed as several subjects had no symptoms during the study. The total score per week fell from 67 to 35 (median values 4 to 2 (daytime) and 4 to 0 (night time)) with budesonide alone and from 44 to 36 (median values 3 to 1 (daytime) and 1 to 0 (night time)) with budesonide plus terbutaline. Changes in the use of ipratropium did not differ significantly between treatments.

$\mathrm{FEV}_{1}, \mathrm{PD}_{20}$ HISTAMINE AND AMP

Changes in $\mathrm{FEV}_{1}$ and $\mathrm{PD}_{20}$ histamine and AMP after cessation of treatment are shown in table 2. Twelve hours after cessation of therapy FEV had increased significantly after budesonide alone (mean change $210 \mathrm{ml}$ (95\% CI 100 to 320); $\mathrm{p}<0.01$ ) but not after budesonide plus terbutaline (mean change $60 \mathrm{ml}(95 \% \mathrm{CI}-100$ to 220$) ; \mathrm{p}>0.4$ ), the difference being of borderline significance (mean difference $150 \mathrm{ml}$ ( $95 \% \mathrm{CI}-10$ to 300$) ; \mathrm{p}=0.06$ ). Both treatments led to an increase in both $\mathrm{PD}_{20}$ histamine and AMP with no significant differences between treatments for change in $\mathrm{PD}_{20}$ histamine (mean difference 0.34 doubling doses $(95 \% \mathrm{CI}$ -0.5 to 1.26 ); $\mathrm{p}>0.3$ ) or $\mathrm{PD}_{20} \mathrm{AMP}$ (mean difference 0.04 doubling doses $(95 \% \mathrm{CI}-1.53$ to 1.59$) ; \mathrm{p}>0.9$ ).

\section{Discussion}

We have compared the airway response during and after two weeks of treatment with budesonide given alone and in combination with regular terbutaline in subjects with mild asthma. Morning and evening PEF rose during both treatments with a significantly greater increase in evening PEF with the combined treatment.
Twelve hours after cessation of treatment FEV, was higher after budesonide alone, although the difference was not statistically significant ( $95 \%$ CI -10 to 300$)$. There were no significant differences between regimens in symptoms during treatment or in change in bronchial reactivity to histamine or AMP after cessation of treatment.

This study was designed to explore the effect of adding regular $\beta$ agonist treatment to corticosteroid treatment following the unexpected finding in a recent parallel group study by Wong et $a l^{20}$ that some of the beneficial effects of budesonide were reduced by the concomitant use of terbutaline. In this earlier study evening PEF was higher in patients taking budesonide plus terbutaline, but following treatment $\mathrm{FEV}_{1}$ and protection against the early response to antigen were greater after budesonide alone. The findings of Dahl et $a l^{23}$ in 37 subjects with nocturnal asthma are also similar in that PEF values were higher during treatment with budesonide combined with oral terbutaline, whilst subject preference and improvement in $\mathrm{FEV}_{1}$ following treatment were greater after budesonide alone, although the latter was not statistically significant. The only other study to compare budesonide with and without terbutaline is difficult to interpret since $\beta$ agonists were used for symptoms during both limbs of the study and the timing of measurements was not given. ${ }^{24}$

In the present study the magnitude of the difference in $\mathrm{FEV}_{1}(150 \mathrm{ml})$ was smaller than that seen in the study by Wong et al $(350 \mathrm{ml})$ and was of borderline statistical significance. It was not associated with a fall in morning PEF, although PEF was measured some 9-10 hours after the last dose of $\beta$ agonist when the high dose of terbutaline $(1000 \mu \mathrm{g})$ may be causing some residual bronchodilatation. There was also no difference between the two treatment regimens for either histamine or AMP responsiveness, in contrast to the greater protection seen against antigen challenge with budesonide alone in the study by Wong et $a l^{20}$ The studies differed in that reactivity was measured 12 hours after the last dose of treatment in this study compared with 33 hours in the study by Wong et al. ${ }^{20}$

The present study does not therefore confirm a negative interaction between corticosteroids and $\beta$ agonists. The difference between our present findings and those of Wong et $a l^{20}$ may be because our previous findings were spurious 
or may be due to differences in timing or, since the trend in the $\mathrm{FEV}_{1}$ in the present study was similar to that in our previous study, it might be due to a type 2 statistical error. On the basis of these findings and our previous study we cannot exclude the possibility that the efficacy of corticosteroids or the duration of their effect is reduced by concurrent treatment with a $\beta$ agonist, although any effect is likely to be small, only apparent once the bronchodilator effect of the $\beta$ agonist has worn off, and the optimum time to detect it has not been determined.

This work was sponsored by a grant from the National Asthma Campaign. We thank Sarah Pacey (Clinical Trials Pharmacist) for handling the drugs and randomisation.

1 Speizer FE, Doll R, Heaf P. Observations on recent increase in mortality from asthma. BMF 1968;1:335-9.

2 Inman WHW, Adelstein AM. Rise and fall of asthma mortality in England and Wales in relation to use of pressurised aerosols. Lancet 1969;ii:279-85.

3 Crane J, Pearce N, Flatt A, Burgess C, Jackson R, Kwong $\mathrm{T}$, et al. Prescribed fenoterol and death from asthma in T, et al. Prescribed fenoterol and death from asthma in New Zealand

4 Pearce N, Grainger J, Atkinson M, Crane J, Burgess C Culling $\mathrm{C}$, et al. Case control study of prescribed fenoterol and death from asthma in New Zealand, 1977-81. Thorax 1990;45:170-5

5 Grainger J, Woodman K, Pearce N, Crane J, Burgess C, Keane A, et al. Prescribed fenoterol and death from asthma in New Zealand, 1981-7: a further case control study. Thorax 1991;46:105-11.

6 Van Arsdel PP, Schaffrin RM, Rosenblatt J, Sprenkle AC, Altman LC. Evaluation of oral fenoterol in chronic asthmatic patients. Chest 1978;73:997-8.

7 Trembath PW, Greenacre JK, Anderson M, Dimmock S Mansfield L, Wadsworth J, et al. Comparison of four weeks' treatment with fenoterol and terbutaline aerosols weeks' treatment with fenoterol and terbutaline aerosols
in adult asthmatics. A double blind crossover study. $f$ Allergy Clin Immunol 1979;63:395-400.

8 Harvey JE, Tattersfield AE. Airway response to salbutamol: effect of regular salbutamol inhalation in normal, atopic and asthmatic subjects. Thorax 1982;37:280-7.

9 Sears MR, Taylor DR, Print CG, Lake DC, Li Q, Flannery $\mathrm{EM}$, et al. Regular inhaled $\beta$ agonist treatment in bronchial asthma. Lancet 1990;336:1391-6.
10 van Schayck CP, Dompeling E, van Herwaarden CLA, Folgering $\mathrm{H}$, Verbeek ALM, van der Hoogen HJM, et al. Bronchodilator treatment in moderate asthma or chronic bronchitis: continuous or on demand? A randomised controlled study. BMF 1991;303:1426-31.

11 Wahedna I, Wong CS, Wisniewski AFZ, Pavord ID, Tattersfield AE. Asthma control during and after cessation of regular beta-agonist treatment. Am Rev Respir Dis 1993; 148:707-12.

12 Kraan J, Kroeter GH, van der Mark TW, Sluiter H, de Vries $\mathrm{K}$. Changes in bronchial hyperreactivity induced by 4 weeks of treatment with anti-asthmatic drugs in patients with allergic asthma: a comparison between budesonide and terbutaline. F Allergy Clin Immunol 1985;76:628-36.

13 Kerrebijn KF, van Essen-Zandvliet EEM of long term treatment with inhaled corticosteroids and $\beta$ agonists on the bronchial responsiveness in children with asthma. F Allergy Clin Immunol 1987;79:653-9.

14 Vathenen AS, Knox AJ, Higgins BG, Britton JR, Tattersfield AE. Rebound increase in bronchial responsiveness after AE. Rebound increase in bronchial responsiveness after

15 Van Schayck CP, Graafsma SJ, Visch MB, Dompeling E, van Weel $C$, van Herwaarden CLA. Increased bronchial hyperresponsiveness after inhaling salbutamol during 1 hyperresponsiveness after inhaling salbutamol during 1 year is not caused by subsensitisation

16 Pearlman DS, Chervinsky P, LaForce C, Seltzer JM, Southern DL, Kemp JP, et al. A comparison of salmeterol with albuterol in the treatment of mild-to-moderate asthma. $N$ Engl f Med 1992;327:1420-5.

17 D'Alonzo GE, Nathan RA, Henochowicz S, Morris RJ, Ratner P, Rennard SI. Salmeterol xinafoate as maintenance therapy compared with albuterol in patients with asthma. $\mathcal{F A M A}$ 1994;271:1412-6.

18 Harrison RN, Mackay AD. Hydrocortisone and bronchial beta-adrenergic responsiveness. Thorax 1980;35:238.

19 Harrison AR, Richards P, Howarth P, Tattersfield AE. Interaction of inhaled corticosteroids and $\beta$ agonists in asthmatic subjects. Thorax 1984;39:710-1.

20 Wong CS, Wahedna I, Pavord ID, Tattersfield AE Effect of regular terbutaline and budesonide on bronchial reof regular terbutaline and budesonide on bronchial reactivity to allergen

21 Peters MJ, Adcock IM, Brown CR, Barnes PJ. $\beta$ agonist inhibition of steroid-receptor DNA binding activity in human lung. Am Rev Respir Dis 1993;147:A772.

22 Higgins BG, Britton JR, Chinn S, Jones TD, Jenkinson D, Burney PGJ, et al. The distribution of peak expiratory flow variability in a population sample. Am Rev Respir Dis 1989;140:1368-72.

23 Dahl R, Pedersen B, Hagglof B. Nocturnal asthma: effect of treatment with oral sustained-release terbutaline, inhaled budesonide, and the two in combination. F Allergy Clin Immunol 1989;83:811-5.

24 Selroos O, Nyholm JE. Influence of a budesonide-terbutaline combination on bronchial hyperreactivity. Clin Exp Allergy 1990;20 (Suppl 1):76. 